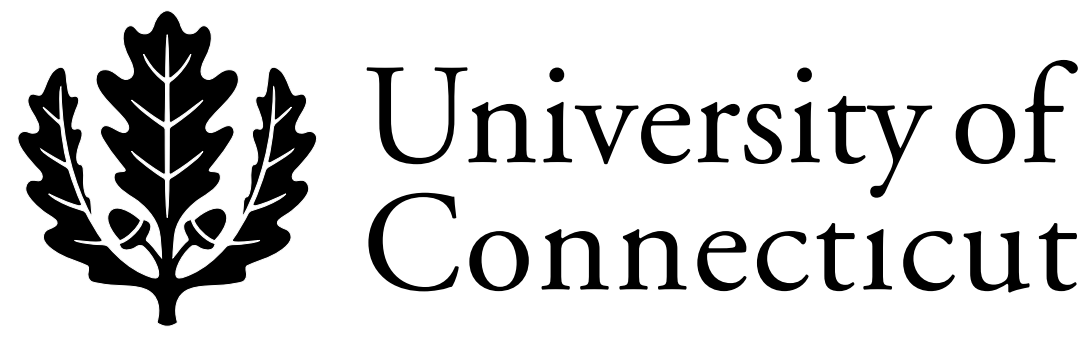

Department of Economics Working Paper Series

Intergeneraltional Conflict nad the Political Economy of School Spending

Ed Baldson

San Diego State University

Eric Brunner

San Diego State University

Working Paper 2003-24

August 2003

341 Mansfield Road, Unit 1063

Storrs, CT 06269-1063

Phone: (860) 486-3022

Fax: (860) 486-4463

http://www.econ.uconn.edu/ 


\begin{abstract}
In this paper we use survey data to examine support among voters from different age cohorts for public school spending. The survey asked potential voters in California how they intended to vote on two initiatives, one a statewide initiative that would increase spending on public schools throughout the state and the other a local initiative that would increase spending only in the respondents local school district. We find that older voters without children generally oppose increases in state spending but are much more willing to support local spending. We examine two explanations for this voting pattern, namely the capitalization of local spending into housing values and intergenerational altruism. Our results do not strongly favor one explanation over the other. Consequently, we conclude that both factors (capitalization and intergenerational altruism) probably play important roles in sustaining support among older voters for local school spending.

For helpful comments on a previous draft of this paper, we are grateful to Jennifer Imazeki and seminar participants at the University of Connecticut and the Public Policy Institute of California. We thank Mark Baldassare and Jon Cohen of the Public Policy Institute of California for providing us with the results of the Institutes statewide survey. This paper was written while Eric Brunner was visiting the University of Connecticut.
\end{abstract}

Journal of Economic Literature Classification: H40, I22, J14

Keywords: School spending, intergenerational conflict, capitalization, altruism 


\section{Introduction}

Over the next three decades the share of elderly individuals in the U.S. population will grow substantially. In 2000, approximately 12.8 percent of the population was age 65 or older. According to the U.S. Census Bureau, that percentage will increase to 20.1 by 2030 . Furthermore, as the baby-boom generation ages, the number of households headed by individuals over the age of 55 is predicted to increase sharply, from 34.9 percent in 2000 to around 39.6 percent in 2010 . Not surprisingly, the growing share of older households will be accompanied by a decline in the share of households with school-age children. For example, U.S. Census Bureau projections indicate the share of family households with school-age children will decline from 46.2 percent in 2000 to 41.3 percent in 2010 . These changes in the demographic structure of the U.S. population have led to growing concern that the next several decades will witness an increase in intergenerational conflict. Of particular concern is how an aging America will affect support for government services that benefit mainly the young, especially $\mathrm{K}-12$ education. If individuals vote in their own self-interest, support for public school spending will likely diminish as the share of older voters without school-age children in the population grows.

Poterba (1997) provides empirical evidence that suggests this concern may be well founded. Using state-level data on K-12 educational expenditures from 1961 to 1991, he finds that, all else equal, perpupil spending declines significantly as the share of the population age 65 or older increases. Poterba also finds that per-capita spending on non-educational related services increases with the share of the population age 65 and older. These results are consistent with an elderly population voting in their own self-interest and suggest that intergenerational conflict over the provision of public goods will likely increase as the population ages.

That conclusion, however, has recently been challenged by two studies. Ladd and Murray (2001) examine support among the elderly for public school spending using county-level data on educational expenditures in 1970, 1980, and 1990. Using a specification similar to that used by Poterba (1997), they find that the share of the population age 65 or older has no effect on county-level per-pupil spending. Harris, Evans and Schwab (2001) examine support among the elderly for public school spending at both the state and school district levels. They find that the elderly's support for public school spending is stronger at the local level than it is at the state level. An increase in the share of elderly significantly reduces support for state-level spending on education but has only a modest negative effect on support for district-level spending.

The purpose of this paper is to provide new evidence on support among voters from different age cohorts for public school spending. Our analysis differs from the previous work on this issue in one key respect. Poterba (1997), Ladd and Murray (2001) and Harris, Evans and Schwab (2001) all use aggregate data on school expenditures and the fraction of elderly within a jurisdiction. By regressing 
either state or local expenditures per pupil on the fraction of the population age 65 or older, these studies provide indirect evidence on how age and the presence of school-age children affects support for public school spending proposals. In contrast, for this study we have the results of an October 2002 survey conducted by the Public Policy Institute of California. The survey asked 2,007 potential voters in California how they intended to vote on two initiatives, one a statewide initiative on the November 2002 ballot that would increase spending on public schools throughout the state, and the other a hypothetical local initiative that would increase spending only in the respondent's own school district. The survey also asked voters their age, whether they had school children, whether or not they were a homeowner, and other demographic questions. Using that information, we can directly examine how support for public school spending varies with a voter's age and whether or not the voter has children in public school. We can also directly examine how support for public school spending differs at the state and local level.

Consistent with the findings of Harris, Evans and Schwab (2001), we find that older voters without children are much less willing to support state-level spending on schools than local spending. In particular, we find that middle-age and elderly voters without children generally oppose increases in state-level spending but are much more willing to support increases in local spending. In section $\mathrm{V}$, we consider two plausible explanations for the voting pattern we observe, namely the capitalization of local spending into housing values, and intergenerational altruism. Our results do not strongly favor one explanation over the other.

\section{The PPIC Survey}

In October 2002, PPIC surveyed 2,007 potential voters concerning issues related to the November 2002 ballot. The survey was conducted by telephone, using a random-dialing procedure, and was restricted to people age eighteen or older. Baldassare (2002) compares the distributions of various characteristics among survey respondents with the distributions of those characteristics from the 2000 Census. He finds that the survey distributions are quite similar to the Census distributions, indicating that the survey was successful in obtaining a representative sample of California residents.

Our analysis focuses on two survey questions. The first asked respondents how they intended to vote on Proposition 47, a statewide initiative that asked voters to approve a $\$ 13.05$ billion dollar bond issue to finance school construction and modernization projects throughout the state. The second asked respondents how they would vote on a hypothetical bond issue that would be used to finance school construction and modernization projects only in their own school districts. Specifically, respondents were asked the following two questions: 


\begin{abstract}
State Initiative
"Also on the November ballot is Proposition 47, the "Kindergarten to University Public Education Facilities Bond Act of 2002." This $\$ 13.05$ billion bond issue will provide funding for necessary education facilities to relieve overcrowding and to repair older schools. The funds will be targeted to areas of greatest need. Funds will also be used to upgrade and build new classrooms in California community colleges, California State University, and the University of California. The projected fiscal impact includes state costs of about $\$ 26.2$ billion over 30 years to pay off the bonds, with payments of about $\$ 873$ million annually. If the election were held today, would you vote yes or no on Proposition 47?"
\end{abstract}

\title{
Local Initiative
}

"If your local school district had a bond measure on the November ballot to pay for school construction projects, would you vote yes or no?"

From the text it is evident that the questions are essentially state and local versions of the same issue, a parallel reinforced by their proximity in the survey. However, they also differ in several important ways that may affect responses. One important difference is the designation of funds raised through the bond measures. As the survey text makes explicit, funds raised from Proposition 47 would be used to finance both University and K-12 school improvements. In contrast, funds raised from the local initiative would be used solely to finance K-12 school improvements. However, we believe this distinction is less important than it may appear. Of the $\$ 13.05$ billion in funding voters were asked to approve with Proposition 47, around 87 percent was earmarked for K-12 schools. If respondents understood that the measure was overwhelmingly for public primary and secondary schools, as it had been presented to the public, it seems unlikely that this distinction had a large impact on responses to the two questions.

A second important difference is in the specific information presented to respondents about the two bond issues. When respondents were asked how they intended to vote on Proposition 47, they were first told the exact amount of the bond issue, the likely financing cost, and the length of the repayment schedule. In contrast, no such information is provided for the hypothetical bond issue. The literature on survey design using referendum-style questions for polling or valuation cautions that wording and details can affect the results of a survey, usually in predictable ways. ${ }^{1}$ For example, if researchers include additional details on cost to a hypothetical referendum designed to illicit voter support for a particular program, the fraction of respondents supporting the program tends to fall. Similarly, greater detail on the benefits of a program tends to increase the fraction of respondents supporting the program. The PPIC's wording of the two survey questions may therefore cause respondents to be less supportive of Proposition 47 than the local measure, which lacks comparable detail on costs. Our concern,

\footnotetext{
${ }^{1}$ See for example Mitchell and Carson (1989).
} 
however, is not with the level of support for state versus local spending but rather with how support for state and local spending varies with the age profile of respondents. As long as voters of all ages interpret the two questions in a similar manner, it seems unlikely that this aspect of the wording of the questions will bias our results.

Finally, a potentially more serious concern is that a large portion of Proposition 47 bond revenue was targeted to high-need areas. According to the California Legislative Analyst's Office, out of the $\$ 11.5$ billion in bond revenue designated for K-12 school improvements, $\$ 6.5$ billion, or 57 percent, was earmarked for backlogged projects and critically overcrowded schools. It is likely that some voters responded to the Proposition 47 question differently than to the local bond referenda question for exactly that reason: they perceived that Proposition 47 funds were not going to be spent on their schools. If the distribution of Proposition 47 spending across communities is correlated with the residential location of old and young voters, this could bias our results. For example, if a larger fraction of young voters live in communities with backlogged projects or overcrowded schools, we might erroneously attribute weak support for Proposition 47 among the elderly to a preference for local over state school spending, when in fact their weak support for state spending is due primarily to where Proposition 47 funding is being targeted. We return to this issue in section IV.

\section{Cross Tabulations of Voter Support for State and Local Initiatives}

We begin by presenting simple cross tabulations of voter support for the state and local initiatives. It is well documented that homeowners and renters tend to have different preferences for school spending. Furthermore, as we discuss in Section V, the effect of age on support for school spending is likely to differ for renters and homeowners. Consequently, rather than pooling renters and homeowners in our sample, we analyze the voting behavior of homeowners and renters separately. The first part of our analysis focuses on the voting behavior of homeowners. We then examine the voting behavior of renters in Section V.

Of the 2,007 respondents in the PPIC survey, 1,193 were homeowners. ${ }^{2}$ Of these 1,193 respondents, 7 did not answer the question about how they intended to vote on Proposition 47 and 6 did not answer the question on how they would vote on a local bond measure, yielding 1,180 observations for our analysis. Of these respondents, 61 percent intended to vote yes on Proposition 47 and 69 percent indicated they would vote yes on a local bond measure.

\footnotetext{
${ }^{2}$ In the survey, 1,207 respondents stated they were homeowners. However, 14 of those respondents under the age of 25 also responded that they had owned their home for 10 years or more. We believe these respondents were actually living in their parent's home and therefore excluded them from the analysis yielding a sample of 1,193 homeowners.
} 
Table 1

Children in School and Support for State and Local Initiatives, Homeowners

\begin{tabular}{l|ccc|ccc} 
& \multicolumn{3}{|c|}{ Intended Vote State Initiative } & \multicolumn{3}{|c}{ Intended Vote Local Initiative } \\
$\begin{array}{l}\text { Presence of School Age } \\
\text { Children } \\
\text { (N) }\end{array}$ & Yes & No & Don't Know & Yes & No & Don't Know \\
\hline $\begin{array}{l}\text { No Children } \\
\quad(719)\end{array}$ & $57.2 \%$ & $33.8 \%$ & $10.0 \%$ & $65.4 \%$ & $27.3 \%$ & $7.3 \%$ \\
$\begin{array}{l}\text { Public School } \\
\quad(392)\end{array}$ & 67.1 & 25.5 & 7.4 & 75.3 & 21.2 & 3.5 \\
$\begin{array}{l}\text { Pre-School Age or } \\
\begin{array}{l}\text { Private School } \\
(68)\end{array}\end{array}$ & 66.2 & 26.5 & 7.3 & 67.7 & 25.0 & 7.3 \\
\hline
\end{tabular}

* One of the 1,180 respondents did not answer the presence of school age children question.

Table 1 presents cross-tabulations of voting percentages by whether or not respondents had children in public school. The PPIC survey allows us to identify three groups of voters: those with no children under the age of 18, those with children in public school, and those with either pre-school age children or children in private school. The Table reports separate voting percentages for each of these groups. As expected, homeowners with children in public school were more likely to support both the statewide initiative and the local initiative. Table 1 also reveals that both homeowners without children and homeowners with children in public school were more likely to support the local initiative than the state initiative.

Table 2 documents how support for the two initiatives varied with the age of respondents. The Table separates homeowners into three groups: all homeowners, those with no children, and those with children in public school. For each group, the Table lists percentages intending to vote for the two initiatives by age group. Columns 3 and 4 of Table 2 reveal that the voting pattern of all homeowners is consistent with the hypothesis that older voters are less likely to support public school spending than younger voters, particularly state-level spending. Column 3 reveals that the fraction of voters supporting the statewide initiative declines with age up to age 55, at which point it increases slightly. Column 4 reveals that a similar pattern holds for the local initiative. That finding is consistent with the results of Vinovskis (1993). Using data from the 1988 American National Election Study, he finds that 77 percent of respondents under that age of 30 supported increases in federal spending for public schools. Furthermore, he finds that support for increased spending declines monotonically with older 
Table 2

Age and Support for State and Local Initiatives, Homeowners

\begin{tabular}{l|ccc|ccc|ccc} 
& \multicolumn{3}{|c|}{$\begin{array}{c}\text { All Homeowners } \\
(1,171)\end{array}$} & \multicolumn{3}{c|}{$\begin{array}{c}\text { No Children } \\
(714)\end{array}$} & \multicolumn{3}{c}{$\begin{array}{c}\text { Children in Public School } \\
(389)\end{array}$} \\
\hline Age & $\mathrm{N}$ & $\begin{array}{c}\text { State } \\
\text { Initiative }\end{array}$ & $\begin{array}{c}\text { Local } \\
\text { Initiative }\end{array}$ & $\mathrm{N}$ & $\begin{array}{c}\text { State } \\
\text { Initiative }\end{array}$ & $\begin{array}{c}\text { Local } \\
\text { Initiative }\end{array}$ & $\mathrm{N}$ & $\begin{array}{c}\text { State } \\
\text { Initiative }\end{array}$ & $\begin{array}{c}\text { Local } \\
\text { Initiative }\end{array}$ \\
\hline $18-34$ & 169 & $74.6 \%$ & $78.1 \%$ & 68 & $77.9 \%$ & $77.9 \%$ & 75 & $74.3 \%$ & $82.6 \%$ \\
$35-44$ & 266 & 65.8 & 74.8 & 81 & 61.7 & 70.4 & 161 & 67.7 & 80.0 \\
$45-54$ & 283 & 56.9 & 64.0 & 159 & 52.8 & 63.5 & 114 & 61.9 & 63.7 \\
$55-64$ & 219 & 55.7 & 66.2 & 180 & 53.3 & 63.3 & 35 & 65.7 & 80.0 \\
65 or older & 234 & 56.0 & 64.5 & 226 & 55.7 & 64.2 & 4 & 100 & 100 \\
\hline
\end{tabular}

* One respondent did not answer the presence of school age children question and eight respondents did not answer the age question yielding a sample of 1,171 homeowners.

age groups (measured in ten year intervals) reaching a low of 46.9 percent among respondents age 70 or older. $^{3}$

A comparison of the voting percentages for voters with no children and those with children in public school reveals that most of the drop off in support for school spending can be attributed to the voting behavior of voters without children. Relative to younger voters, the percentage of voters without children favoring both the state and local initiatives declines markedly among voters age 45 or older, although the drop off in support among older voters is much stronger for the statewide initiative. In contrast, for voters with children in public school there is no clear relationship between age and support for either the state or local initiative. While voters with children in public school between the ages of 45 and 54 appear less likely to support either initiative relative to voters in other age groups, in general the oldest voters don't appear to vote much differently than younger voters. Rubinfeld (1977) reaches a similar conclusion. Using a survey of voters in two local school elections in the Detroit area, he finds that, conditional on having children in public school, age has no effect on support for public school spending. He also finds that voters with children in public school are much more likely to support public school spending.

\footnotetext{
${ }^{3}$ Ponza et al. (1988) obtain similar results using data from the 1986 General Social Survey. Specifically, they find that 74 percent of respondents under the age of 35 believed spending on public education was too low. In contrast, only $50 \%$ of respondents age 65 or older believed spending on public education was too low.
} 


\section{Multivariate Analysis}

The results reported in Table 2 suggest that, relative to younger voters, older voters without children are less likely to support school spending, particularly state-level spending. However, those results do not control for other factors, such as income, education and ideology that might be correlated with both the demand for school spending and age. We therefore turn to multivariate analysis to isolate the impact of age on support for school spending. We begin by estimating a binary logit model using data only from those respondents who stated they would vote yes or no on the statewide and local initiatives and exclude those who stated they did not know how they would vote on these initiatives. We then expand our analysis to include those voters who did not know how they would vote and estimate an ordered logit model in which voters that stated they did not know how they would vote are classified as indifferent.

Table 3 lists the explanatory variables we use in our analysis. We use the same set of variables to explain voting behavior on the statewide initiative and the local initiative. We define four age dummies to examine the impact of age on support for public school spending: the omitted group in the analysis that follows is always voters between the ages of 18 and 34. Since conservative voters tend to be less supportive of increases in government spending in general, we expect ideology to have a negative effect on support for both the statewide and local initiatives. Prior studies that use survey data to estimate the demand for public education generally find that, all else equal, women tend to have higher demand for public school spending than men. ${ }^{4}$ Consequently, we also include a dummy variable that takes the value of unity if the respondent is female.

We include two other explanatory variables that deserve discussion. The first variable is the respondent's expectations of the future economic conditions in California. Specifically, respondents were asked: "Turning to the economic conditions in California, do you think that during the next 12 months we will have good times financially or bad times?" As noted by Inman (1983) and Holtz-Eakin and Rosen (1993), expectations about future income and other economic conditions should play a critical role in models of demand for local public capital. We therefore include a dummy variable that takes the value of unity if the respondent expected good economic conditions during the next 12 months.

\footnotetext{
${ }^{4}$ See for example, Rubinfeld (1977) and Bergstrom, Rubinfeld and Shapiro (1982).
} 
Table 3

Description of Explanatory Variables

\begin{tabular}{|c|c|}
\hline Variable & Description \\
\hline Age 35-44 & $1=35$ to $44,0=$ all other age groups \\
\hline Age 45-54 & $1=45$ to $54,0=$ all other age groups \\
\hline Age 55-64 & $1=55$ to $64,0=$ all other age groups \\
\hline Age $65+$ & $1=65$ or older, $0=$ all other age groups \\
\hline Ideology & $\begin{array}{l}1=\text { very liberal, } 2=\text { somewhat liberal, } \\
3=\text { middle-of-the-road, } 4=\text { somewhat conservative, } 5=\text { very } \\
\text { conservative }\end{array}$ \\
\hline White & $\begin{array}{l}1=\text { Caucasian or White and not Hispanic, } \\
0=\text { all other groups }\end{array}$ \\
\hline Female & $1=$ female, $0=$ male \\
\hline Income & $\begin{array}{l}1=\text { under } \$ 20,000 ; 2=\$ 20,000 \text { to } \$ 39,999 ; \\
3=\$ 40,000 \text { to } \$ 59,999 ; 4=\$ 60,000 \text { to } \$ 79,999 ; 5=\$ 80,000 \text { to } \\
\$ 99,999 ; 6=\$ 100,000 \text { or more }\end{array}$ \\
\hline College & $1=$ college graduate or post-graduate, $0=$ all other education levels \\
\hline Outlook & $\begin{array}{l}1=\text { good financial times over next year, } 0=\text { bad financial times or } \\
\text { uncertain financial times over next year }\end{array}$ \\
\hline Years in Current Residence & $\begin{array}{l}1=\text { less than } 5 \text { years, } 2=5 \text { to } 9 \text { years, } 3=10 \text { to } 19 \text { years, } 4=20 \\
\text { years or longer }\end{array}$ \\
\hline
\end{tabular}

The second variable is the number of years a homeowner has lived in their current residence. Our reason for including this variable is related to Proposition 13, a 1978 statewide proposition that capped property tax rates at one percent of assessed valuation throughout the state. Proposition 13 also changed when and how property was assessed for tax purposes in California. Specifically, after the passage of Proposition 13, property could only be reassessed upon a change in ownership, at which point the property was assessed at full market value. As a result, the assessed value and market value of homes in California can differ substantially depending on when a home was purchased. In general, the longer a resident has lived in their home, the larger the gap between market value and assessed value. Since years of current home ownership is undoubtedly positively correlated with age, older voters are likely to face a lower tax price for school spending than younger voters. ${ }^{5}$ If we did not control for

\footnotetext{
${ }^{5}$ The simple correlation between years in current residence and the age of homeowners with no children in our sample is 0.42 , confirming that age and the number of years a homeowner has owned their current home are strongly positively correlated.
} 
years in current residence in our analysis, this positive correlation could lead us to understate the effect of age on support for local school spending.

The survey data have a number of limitations. The first limitation concerns missing observations. Two respondents did not answer the question about educational attainment and an additional four respondents did not answer the question about future economic conditions. We excluded these respondents from the analysis. A larger number of respondents did not answer the questions about income, ethnicity and ideology. Specifically, 95 respondents failed to answer the income question, 29 failed to answer the ethnicity question and 17 failed to answer the ideology question. Rather than exclude these respondents from our analysis, we created three dummy variables indicating whether observations on income, ethnicity or ideology were missing. These dummy variables take the value of unity if the observation is missing and zero otherwise. We then included the income, ethnicity and ideology variables (with missing values recoded to zero) and the three missing value dummy variables in our analysis.

Finally, as we noted earlier, the PPIC survey allows us to identify three groups of voters: those with no children under the age of 18 , those with children in public school and those with either preschool age children or children in private school. The last group is problematic since it combines two groups that most likely have very different preferences for school spending. We would expect voters with children in private school to oppose increases in public school spending. In contrast, given that most students attend public schools, we would expect the majority of voters with pre-school age children to support increases in public school spending. Because we can't separate voters with preschool children and voters with private school children, we proceed by focusing only on voters with no children and voters with children in public school. Our final sample consists of 607 voters without children and 351 voters with children in public school that stated they would vote yes or no on the statewide and local initiatives.

Sample means of the variables used in our analysis are reported in Table 4. The mean of each variable is reported separately for voters with no children and voters with children in public school. As expected, voters with no children tend to be older than voters with children in public school.

Furthermore, consistent with the changing demographic patterns in California, a larger fraction of voters with no children tended to be white. 
Table 4

Sample Means, Homeowners

\begin{tabular}{|c|c|c|}
\hline Variable & No Children & $\begin{array}{c}\text { Children in } \\
\text { Public School }\end{array}$ \\
\hline Vote on State Initiative $(1=$ yes, $0=$ no $)$ & 0.64 & 0.73 \\
\hline Vote on Local Initiative ( $1=$ yes, $0=$ no) & 0.70 & 0.77 \\
\hline Age $35-44$ & 0.11 & 0.40 \\
\hline Age $45-54$ & 0.23 & 0.30 \\
\hline Age 55-64 & 0.26 & 0.09 \\
\hline Age $65+$ & 0.30 & 0.01 \\
\hline Ideology $^{\mathrm{a}}$ & 3.08 & 3.08 \\
\hline White $^{\mathrm{b}}$ & 0.79 & 0.64 \\
\hline Female & 0.52 & 0.51 \\
\hline Income $^{c}$ & 3.74 & 4.04 \\
\hline College & 0.50 & 0.48 \\
\hline Outlook & 0.37 & 0.39 \\
\hline Years in Current Residence & 2.62 & 2.05 \\
\hline Number of Observations & 607 & 351 \\
\hline
\end{tabular}

${ }^{a}$ mean does not include 17 respondents who did not answer the ideology question.

${ }^{\mathrm{b}}$ mean does not include 29 respondents who did not answer the ethnicity question.

${ }^{\mathrm{c}}$ mean does not include 95 respondents who did not answer the income question.

\section{Binary Logit and Ordered Logit Results}

Results for the binary logit model are reported in Table 5. We use interaction terms to allow the effect of age to differ for homeowners without children and homeowners with children in public school. Specifically, we created two sets of interaction terms. The first set is the interaction of the age dummies with a dummy variable that takes the value of unity for homeowners without children. The second set is the interaction of the age dummies with a dummy variable that takes that value of unity for homeowners with children in public school. Note that the control group for the age coefficients is all homeowners under the age of 35. Thus, the age coefficients reported in the first four rows of Table 5 reveal the effect 
of age on support for public school spending for voters without children relative to voters under the age of 35. Similarly, the age coefficients reported in the next three columns reveal the effect of age on support for public school spending for voters with children relative to voters under the age of $35 .^{6}$ Among the voters with children in public school, only four were age 65 or older and all four of those respondents stated they would support both the state and local initiatives. Consequently the age 65 or older dummy for voters with children in public school perfectly predicts a yes vote. We therefore combined the age 55-64 and age 65+ groups for the voters with children in public school and created a new dummy variable, age 55+, that takes the value of unity if a voter with children in public school is 55 or older. $^{7}$

Columns 2 and 4 of Table 5 report the estimated logit coefficients for the statewide and local initiatives respectively. Columns 3 and 5 report associated marginal effects evaluated for a respondent with the median characteristics: under the age of 35, ideologically "middle of the road," white, female, income between $\$ 40,000$ and $\$ 59,999$, no college degree, a pessimistic view of future economic conditions, and 5 to 10 years in their current residence. ${ }^{8}$ In the statewide regression, all the estimated age coefficients for homeowners without children are negative and all but one (the age 35 to 44 coefficient) are statistically different from zero at the ten-percent level or better. Thus, our results suggest that older voters without children are significantly less likely to support state-level public school spending than young voters. For example, based on the marginal effects reported in column three, our results suggest that homeowners without children between the ages of 45 and 54 are 24 percentage points less likely to vote yes on the statewide initiative than homeowners under the age of 35 . Similarly, homeowners without children between the ages of 55 and 64 are 20 percentage points less likely to vote yes on the statewide initiative. For homeowners with children in public school the effect of age is less clear. Homeowners with children between the ages of 45 and 54 are less likely than younger voters to support state-level spending. However, homeowners with children between the ages of 35 and 44 and 55 and 64 are no less likely to support state-level spending.

\footnotetext{
${ }^{6}$ Our empirical model assumes support for school spending among voters under the age of 35 does not depend on whether or not a voter has children in public school. To test the validity of that assumption, we estimated an expanded model that included a dummy variable that takes the value of unity if a homeowner had children in public school. This allows support for school spending among voters under the age of 35 to vary by whether or not they have children in public school. The estimated coefficient on this dummy variable was statistically insignificant in both the binary and ordered logit models suggesting that all voters under the age of 35 have similar preferences for school spending.

${ }^{7} \mathrm{We}$ also re-estimated the model excluding the four voters with children in public school who were 65 or older. The results were qualitatively and quantitatively similar to those reported in Table 5.

${ }^{8}$ For dummy variables the marginal effects are calculated using the change in the value of a dummy variable from zero to one.
} 
Table 5

Binary Logit, Homeowners $(\mathrm{N}=958)$

Standard Errors in Parenthesis

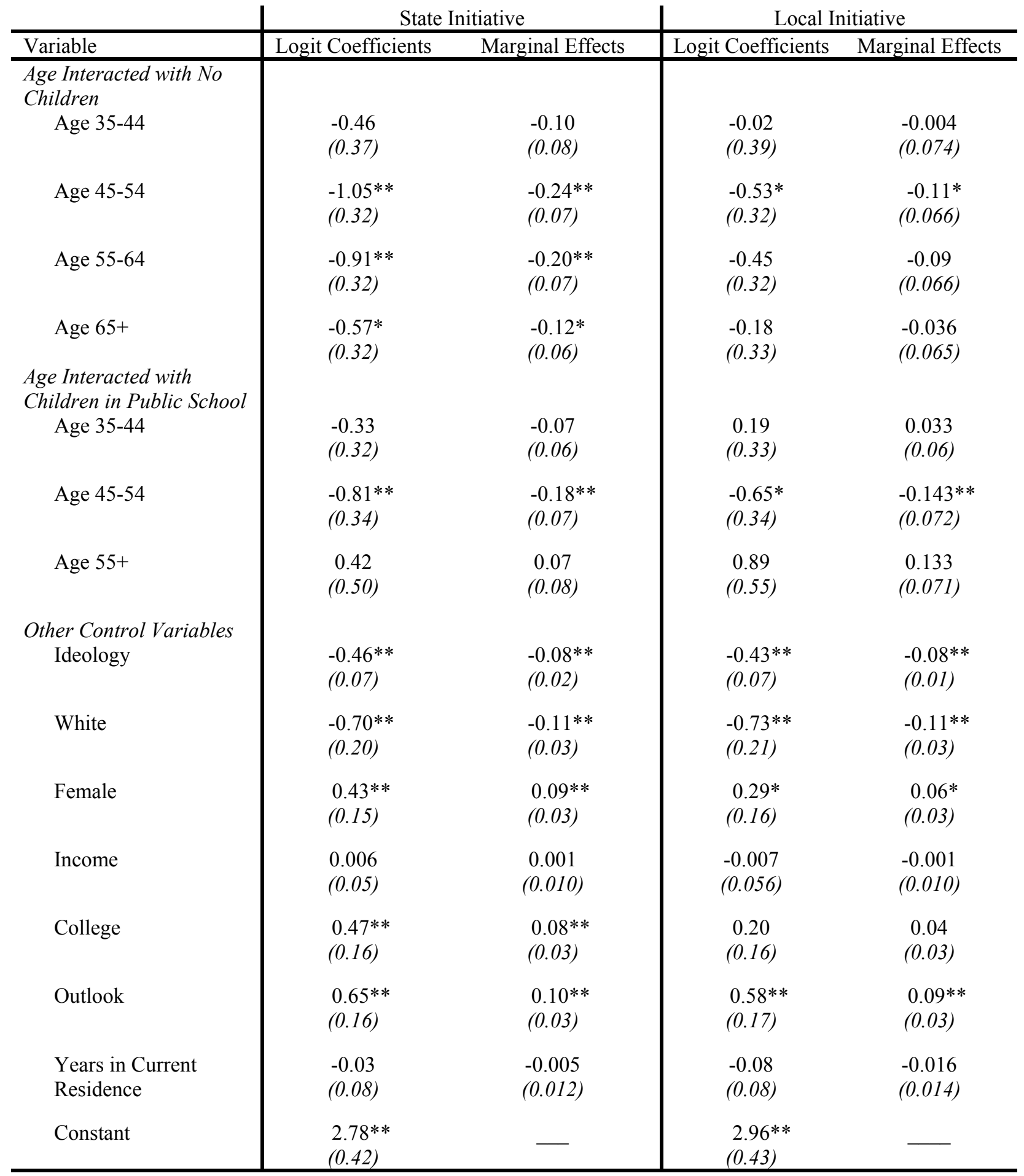

*Significant at 10 percent level.

**Significant at 5 percent level. 
In the local regression, all the estimated age coefficients for homeowners without children are once again negative. However, in contrast to the statewide results, only one of the age coefficients is statistically significant. More importantly, a comparison of the marginal effects reported in columns 3 and 5 reveals that age has a much larger effect on support for state spending than it does on support for local spending: all the estimated marginal effects for the age dummies in the local regression are much smaller in magnitude. For example, while homeowners without children between the ages of 55 and 64 are 20 percentage points less likely to vote yes on the statewide initiative than younger voters, they are only 9 percentage points less likely to vote yes on the local initiative. Our results therefore suggest that middle-age and elderly voters without children are much less likely to support state level spending than local spending, a finding consistent with Harris, Evans and Schwab (2001).

The estimates reported in Table 5 are based on a sample that excluded 139 respondents that stated they did not know how they would vote on the statewide and local initiatives. To incorporate those respondents into our analysis, we assume voters that stated they did not know how they would vote were indifferent about the outcome of an initiative. Specifically, for each initiative we define a new variable that takes a value of 3 if a respondent intended to vote yes, a value of 2 if the respondent was indifferent, and a value of 1 if the respondent intended to vote no. We then use these new dependent variables to estimate an ordered logit model.

Table 6 reports estimates from the ordered logit model. The results are qualitatively similar to those reported in Table 5. In the statewide regression, with the exception of the coefficient on the age 35 to 44 dummy, all of the coefficients on the age dummies for homeowners without children are negative and statistically significant at the ten-percent level or better. Furthermore, the marginal effects reported in columns 3 and 5 of Table 6 once again suggest that homeowners without children are much less likely to support state spending than local spending. The age coefficients for homeowners with children in public school are also similar to those reported in Table 5. Specifically, among homeowners with children in public school, only voters between the ages of 45 and 54 appear less likely than younger voters to support either the statewide or local initiative. 
Table 6

Ordered Logit, Homeowners ( $\mathrm{N}=1,097)$

Standard Errors in Parenthesis

\begin{tabular}{|c|c|c|c|c|}
\hline & \multicolumn{2}{|c|}{ State Initiative } & \multicolumn{2}{|c|}{ Local Initiative } \\
\hline Variable & Logit Coefficients & Marginal Effects & Logit Coefficients & Marginal Effects \\
\hline $\begin{array}{l}\text { Age Interacted with No } \\
\text { Children } \\
\quad \text { Age 35-44 }\end{array}$ & $\begin{array}{l}-0.46 \\
(0.31)\end{array}$ & $\begin{array}{l}-0.11^{*} \\
(0.07)\end{array}$ & $\begin{array}{l}-0.25 \\
(0.33)\end{array}$ & $\begin{array}{l}-0.05 \\
(0.07)\end{array}$ \\
\hline Age 45-54 & $\begin{array}{l}-0.91^{* *} \\
(0.27)\end{array}$ & $\begin{array}{l}-0.22 * * \\
(0.06)\end{array}$ & $\begin{array}{l}-0.61^{* *} \\
(0.28)\end{array}$ & $\begin{array}{l}-0.14^{* *} \\
(0.06)\end{array}$ \\
\hline Age 55-64 & $\begin{array}{l}-0.75^{* *} \\
(0.26)\end{array}$ & $\begin{array}{l}-0.18^{* *} \\
(0.06)\end{array}$ & $\begin{array}{l}-0.55^{*} \\
(0.28)\end{array}$ & $\begin{array}{l}-0.12 * * \\
(0.06)\end{array}$ \\
\hline Age $65+$ & $\begin{array}{l}-0.50^{*} \\
(0.26)\end{array}$ & $\begin{array}{l}-0.12^{* *} \\
(0.06)\end{array}$ & $\begin{array}{l}-0.34 \\
(0.28)\end{array}$ & $\begin{array}{l}-0.07 \\
(0.06)\end{array}$ \\
\hline $\begin{array}{l}\text { Age Interacted with } \\
\text { Children in Public School } \\
\quad \text { Age } 35-44\end{array}$ & $\begin{array}{l}-0.26 \\
(0.26)\end{array}$ & $\begin{array}{l}-0.06 \\
(0.06)\end{array}$ & $\begin{array}{c}0.04 \\
(0.29)\end{array}$ & $\begin{array}{c}0.007 \\
(0.058)\end{array}$ \\
\hline Age 45-54 & $\begin{array}{l}-0.60^{* *} \\
(0.29)\end{array}$ & $\begin{array}{l}-0.14^{* *} \\
(0.07)\end{array}$ & $\begin{array}{l}-0.67 * * \\
(0.30)\end{array}$ & $\begin{array}{l}-0.15^{* *} \\
(0.07)\end{array}$ \\
\hline Age 55+ & $\begin{array}{c}0.17 \\
(0.39)\end{array}$ & $\begin{array}{c}0.04 \\
(0.08)\end{array}$ & $\begin{array}{c}0.71 \\
(0.47)\end{array}$ & $\begin{array}{c}0.12 \\
(0.07)\end{array}$ \\
\hline $\begin{array}{l}\text { Other Control Varlables } \\
\text { Ideology }\end{array}$ & $\begin{array}{l}-0.42 * * \\
(0.06)\end{array}$ & $\begin{array}{l}-0.09 * * \\
(0.01)\end{array}$ & $\begin{array}{l}-0.41 * * \\
(0.06)\end{array}$ & $\begin{array}{l}-0.08^{* *} \\
(0.01)\end{array}$ \\
\hline White & $\begin{array}{l}-0.62 * * \\
(0.16)\end{array}$ & $\begin{array}{l}-0.12 * * \\
(0.03)\end{array}$ & $\begin{array}{l}-0.68^{* *} \\
(0.18)\end{array}$ & $\begin{array}{l}-0.11 * * \\
(0.03)\end{array}$ \\
\hline Female & $\begin{array}{l}0.41 * * \\
(0.13)\end{array}$ & $\begin{array}{l}0.09 * * \\
(0.03)\end{array}$ & $\begin{array}{l}0.31^{* *} \\
(0.14)\end{array}$ & $\begin{array}{l}0.068^{* *} \\
(0.030)\end{array}$ \\
\hline Income & $\begin{array}{c}0.01 \\
(0.05)\end{array}$ & $\begin{array}{l}0.003 \\
(0.010)\end{array}$ & $\begin{array}{l}0.03 \\
(0.05)\end{array}$ & $\begin{array}{c}0.007 \\
(0.009)\end{array}$ \\
\hline College & $\begin{array}{l}0.32 * * \\
(0.14)\end{array}$ & $\begin{array}{l}0.07 * * \\
(0.03)\end{array}$ & $\begin{array}{c}0.13 \\
(0.14)\end{array}$ & $\begin{array}{c}0.03 \\
(0.03)\end{array}$ \\
\hline Outlook & $\begin{array}{l}0.60^{* *} \\
(0.14)\end{array}$ & $\begin{array}{l}0.12 * * \\
(0.03)\end{array}$ & $\begin{array}{l}0.59^{* *} \\
(0.15)\end{array}$ & $\begin{array}{l}0.10^{* *} \\
(0.03)\end{array}$ \\
\hline $\begin{array}{l}\text { Years in Current } \\
\text { Residence }\end{array}$ & $\begin{array}{l}-0.01 \\
(0.06)\end{array}$ & $\begin{array}{l}-0.003 \\
(0.013)\end{array}$ & $\begin{array}{l}-0.05 \\
(0.07)\end{array}$ & $\begin{array}{l}-0.009 \\
(0.013)\end{array}$ \\
\hline Lower Cutoff & $\begin{array}{l}-2.68 * * \\
(0.35)\end{array}$ & - & $\begin{array}{l}-2.85^{* *} \\
(0.38)\end{array}$ & - \\
\hline Upper Cutoff & $\begin{array}{l}-2.23 * * \\
(0.35)\end{array}$ & 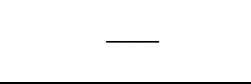 & $\begin{array}{l}-2.53 * * \\
(0.38)\end{array}$ & 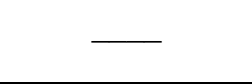 \\
\hline
\end{tabular}

*Significant at 10 percent level.

**Significant at 5 percent level. 
The coefficients on the age dummies for homeowners without children in the binary and ordered logit regressions reveal another interesting pattern. The coefficients decline in magnitude (increasing support for the measure) with older groups after age 35-44, a pattern that holds for both the statewide and local initiative. With self-interested voting behavior, the greater support among voters between the ages of 35 and 44 is expected: undoubtedly some of these voters are still considering having children and those children will most likely attend public schools in the future. However, it is unlikely that voters in the age 45-54, age 55-64 or age 65 or older categories are still considering having children. Consequently, with self-interested voting behavior, one would expect voters without children in all three of these age groups to be equally opposed to increases in school spending. Our results, however, indicate otherwise. For example, the results reported in column 3 of Table 5, reveal that while homeowners without children between the ages of 45 and 54 are 24 percentage points less likely than younger voters to support the state initiative, homeowners without children over the age of 65 are only 12 percentage points less likely to support the statewide initiative. ${ }^{9}$

That the elderly appear to be more "generous" than other individuals is not entirely surprising given the literature on voluntary contributions. Numerous studies have found that, controlling for income, education and a variety of other factors, voluntary contributions increase markedly with age. ${ }^{10}$ Clotfelter (1997) and others have argued that the relative generosity of the elderly in terms of voluntary giving is most likely due to life-cycle effects. Individuals of all generations simply become more generous as death approaches. One form of a life-cycle effect that may explain why elderly voters are more willing to support school spending than middle-age voters is intergenerational altruism. Specifically, relative to middle-age voters without children, elderly voters are more likely to have grandchildren who attend public schools in their local community or within the state. Consequently, they are more likely to be altruistically linked to the current generation of school children and thus be more willing to support school spending.

While life-cycle effects could certainly explain why elderly voters appear more willing to support school spending than middle-age voters without children, Putnam (1995) offers a different explanation. He argues that the propensity of the elderly to be more generous has more to do with generational or cohort effects than simple life-cycle effects. Using data from the General Social Survey (GSS) he finds that the inclination to engage in civil society, everything from the involvement in community organizations to voting, is much stronger among elderly Americans than among baby

\footnotetext{
${ }^{9}$ Furthermore, the results of a likelihood ratio test for the equality of parameter estimates reveals that, in the state initiative regressions, the two coefficients are statistically different from each other at the ten-percent significance level in both the binary and ordered logit models. However, in the local initiative regressions one cannot reject the null hypothesis that the two coefficients are the same.

${ }^{10}$ See for example, Auten and Joulfaian (1996) and Randolph (1995). For an overview of estimated age effects in studies of charitable giving see Clotfelter (1985).
} 
boomers. ${ }^{11}$ Furthermore, he finds that the pattern of civic engagement is inconsistent with simple lifecycle effects but strongly consistent with generational effects.

Whether the generosity of the elderly has more to do with life-cycle effects or generational effects has important implications for the future support of public school spending. If the generosity of the elderly is due to life-cycle effects, the lack of support for public school spending among middle-age voters without children may diminish over time as these voters age. In contrast, if the generosity of the elderly has more to do with generational effects, support for public school spending, particularly statelevel spending, may continue to decline as the baby-boom generation ages. We return to this issue in Sections V and VI.

\section{Targeted State Funding and Tiebout Sorting}

As we discussed in section II, one potential concern with the estimates reported in Tables 5 and 6 is that a large portion of Proposition 47 funding was targeted to high-need areas. If the distribution of old and young voters within the state varies with where Proposition 47 funds were likely to be spent, our state-level estimates of the impact of age on support for school spending will be biased. One method of controlling for this problem is to focus only on within-community variation in the age distribution of voters and support for the statewide initiative. By eliminating unobservable community-specific effects from our analysis, we essentially eliminate any correlation between the age profile of voters and the distribution of Proposition 47 funding. While we do not know the school district in which respondents live, we do know which county they live in. As a result, we can estimate a fixed effects logit model that controls for any county-specific effects that may be correlated with the age distribution of voters.

Focusing on within-county variations also helps address another problem that may affect our local initiative estimates, namely Tiebout bias. To illustrate the potential for Tiebout bias consider the following example. Suppose that voters sort themselves among communities according to their demand for public school quality. Elderly voters sort themselves into communities with relatively low spending per pupil to avoid paying high property taxes, while young voters who are considering having children sort themselves into communities with relatively high spending per pupil. The age distribution of voters would then be correlated with unobservable community characteristics, such as the reputation of a community for having high-quality schools. This in turn would cause the age profile of voters in our sample to be negatively correlated with the error term. As a result, our local estimates would tend to overstate the effect of age on local support for local school spending.

Focusing only on within-county variations helps eliminate the potential for Tiebout bias since it eliminates any correlation between the error term in our model and the age profile of voters across

\footnotetext{
${ }^{11}$ In particular see Table 5 in Putnam (1995).
} 
counties. However, as noted by Ladd and Murray (2001), it may not eliminate Tiebout bias. To the extent that most sorting occurs within counties rather than across counties, the potential for Tiebout bias remains. We do not know how serious a problem this is, however, the results of several studies suggest that county fixed effects remove most of the bias introduced by Tiebout sorting. For example, in their analysis of the relationship between county-level spending per pupil and the fraction of the population age 65 or older, Ladd and Murray (2001) use instrumental variables in an attempt to control for any Tiebout bias that might remain after including county fixed effects. They find that the coefficient estimates from the models that include county fixed effects, but do not instrument for the fraction of the population age 65 or older, are similar to those found when both county fixed effects and instrumental variable techniques are used. Harris, Evans and Schwab (2001) reach a similar conclusion.

Specifically, they find that, once county fixed effects have been included, controlling for within-county sorting using instrumental variables reduces the magnitude of the coefficient on the fraction of the population age 65 or older but only slightly.

Parameter estimates for the fixed-effects logit model are presented in Table 7. The parameter estimates for the statewide initiative are similar to those reported in the second column of Table 5, suggesting that the targeting of state funds to high-needs areas does not significantly bias our estimates. Controlling for county specific fixed effects has a larger impact on our local initiative estimates. For homeowners without children none of the age coefficients are statistically different from zero. Furthermore, with the exception of the coefficient on age 35 to 44 , all of the age coefficients for homeowners without children reported in Table 7 are smaller in magnitude than those reported in column 4 of Table 5. For example, the point estimate for the age 55 to 64 reported in Table 5 is -0.45 . In the fixed effects logit model, the point estimate on that dummy falls to -0.25 . That finding is consistent with the hypothesis that our local estimates tend to overstate the effect of age on local support for local school spending when Tiebout sorting is not accounted for. 
Table 7

Fixed Effect Logit, Homeowners

Standard Errors in Parenthesis

\begin{tabular}{|c|c|c|}
\hline Variable & State Initiative & Local Initiative \\
\hline $\begin{array}{l}\text { Age Interacted with No Children } \\
\text { Age } 35-44\end{array}$ & $\begin{array}{l}-0.56 \\
(0.38)\end{array}$ & $\begin{array}{l}-0.07 \\
(0.39)\end{array}$ \\
\hline Age $45-54$ & $\begin{array}{l}-1.04^{* *} \\
(0.33)\end{array}$ & $\begin{array}{l}-0.41 \\
(0.34)\end{array}$ \\
\hline Age 55-64 & $\begin{array}{l}-0.83^{* *} \\
(0.34)\end{array}$ & $\begin{array}{l}-0.25 \\
(0.34)\end{array}$ \\
\hline Age 65+ & $\begin{array}{l}-0.52 \\
(0.34)\end{array}$ & $\begin{array}{c}0.02 \\
(0.35)\end{array}$ \\
\hline $\begin{array}{l}\text { Age Interacted with Children in } \\
\text { Public School } \\
\text { Age 35-44 }\end{array}$ & $\begin{array}{l}-0.21 \\
(0.33)\end{array}$ & $\begin{array}{c}0.31 \\
(0.35)\end{array}$ \\
\hline Age $45-54$ & $\begin{array}{l}-0.77 * * \\
(0.35)\end{array}$ & $\begin{array}{l}-0.57 \\
(0.35)\end{array}$ \\
\hline Age 55+ & $\begin{array}{c}0.49 \\
(0.51)\end{array}$ & $\begin{array}{l}1.03 * \\
(0.56)\end{array}$ \\
\hline $\begin{array}{l}\text { Other Control Variables } \\
\text { Ideology }\end{array}$ & $\begin{array}{l}-0.44^{* *} \\
(0.07)\end{array}$ & $\begin{array}{l}-0.41^{* *} \\
(0.08)\end{array}$ \\
\hline White & $\begin{array}{l}-0.62^{* *} \\
(0.21)\end{array}$ & $\begin{array}{l}-0.76^{* *} \\
(0.22)\end{array}$ \\
\hline Female & $\begin{array}{l}0.46^{* *} \\
(0.16)\end{array}$ & $\begin{array}{r}0.28^{*} \\
(0.16)\end{array}$ \\
\hline Income & $\begin{array}{c}0.003 \\
(0.057)\end{array}$ & $\begin{array}{l}-0.01 \\
(0.06)\end{array}$ \\
\hline College & $\begin{array}{l}0.46^{* *} \\
(0.17)\end{array}$ & $\begin{array}{c}0.17 \\
(0.17)\end{array}$ \\
\hline Outlook & $\begin{array}{l}0.71^{* *} \\
(0.17)\end{array}$ & $\begin{array}{l}0.63 * * \\
(0.18)\end{array}$ \\
\hline $\begin{array}{l}\text { Years in Current } \\
\text { Residence }\end{array}$ & $\begin{array}{l}-0.07 \\
(0.08)\end{array}$ & $\begin{array}{l}-0.15^{*} \\
(0.08)\end{array}$ \\
\hline Observations & 927 & 914 \\
\hline
\end{tabular}

*Significant at 10 percent level.

**Significant at 5 percent level. 


\section{Capitalization, Altruism, and Support for School Spending}

Tables 5 through 7 consistently demonstrate that middle-age and elderly homeowners without children are more likely to support local spending than state spending on schools. In Table 5 for example, the estimated marginal effects for the age dummies in the local regression are all less than half the magnitude of the corresponding marginal effects in the statewide regression. If the age coefficients are effectively measuring a decline in the value of improved school quality to older voters, what causes the strong preference for local over state spending?

As noted by Harris, Evans and Schwab (2001), one likely explanation is capitalization. An increase in state spending improves the quality of all schools within a state, leaving the overall distribution of school quality unchanged. Since capitalization derives from relative differences in school quality across communities, capitalization of state spending is unlikely. In contrast, when a local community decides to increase school spending, school quality in that district rises relative to neighboring districts. The relative rise in school quality attracts families with children to the community causing the spending increase to be capitalized into housing values. While neither an increase in state nor local spending offers older homeowners without children any direct benefit, the capitalization of local school spending into housing provides a clear motivation for these voters to prefer an increase in local versus state spending. ${ }^{12}$

Of course capitalization is only a valid explanation of the voting pattern we observe if homeowners are aware of what causes capitalization. Is the voting behavior of homeowners really guided by the likely impact of voting outcomes on their housing values? Fischel (2001a, 2001b) emphatically argues that the answer to this question is yes. As he points out, for most homeowners, their home constitutes the vast majority of their wealth. As a result, they are likely to be keenly aware of the factors that affect the value of their largest asset. Fischel describes individuals motivated exclusively by capitalization effects as "homevoters." To a homevoter, local and statewide financing of the same public good would represent very different proposals.

Both the theoretical and empirical local public finance literature contains significant evidence that capitalization influences voting behavior. For example, on the theoretical side, Brueckner and Joo (1991) develop a model of voting behavior on municipal capital spending (such as the construction of a new school) in the presence of capitalization. They demonstrate that with capitalization, the voting behavior of homeowners will reflect both their own preferences for capital spending and those of

\footnotetext{
${ }^{12}$ Numerous studies find school quality is in fact capitalized into housing values (see for example, Oates, 1969; Bogart and Cromwell, 1997; and Black, 1999). A weaker link may exist between school facilities and quality (usually measured by student performance), but the validity of capitalization as a theory of behavior in this case rests on voters' belief that better facilities attract young families to the community, not on actual educational quality improvements.
} 
potential buyers of their home. As a result, elderly voters who receive no direct consumption benefit from a construction project may still vote in favor of the project to enhance the value of their home to a potential buyer.

On the empirical side, Brunner and Sonstelie (2003) provide perhaps the most direct evidence that capitalization affects voting behavior. Using survey data, they examine the voting behavior of homeowners without children on a 2000 school voucher initiative in California. Although the educational opportunities provided by a voucher may be of little concern to homeowners without children, the potential impact of a voucher on property values may be a much bigger concern. As the authors note, homes located in communities with good public schools sell at a premium. By subsidizing private competitors, a voucher would reduce the premium families were willing to pay to live in communities with good schools, causing property values in those communities to fall. These potential capital losses would affect all homeowners, including those without children. The authors find that, all else equal, homeowners without children were significantly less likely to vote for the voucher if they lived in a community with good public schools, supporting the hypothesis that the voting behavior of homeowners was guided by a desire to protect property values.

While capitalization certainly could explain why older homeowners without children prefer local over state spending, another likely explanation is intergenerational altruism. ${ }^{13}$ As noted by Poterba (1998) and Ladd and Murray (2001), to the extent that the elderly care about the welfare of future generations, altruism could reduce their opposition to spending on education. We also observed earlier, in Tables 5-7, that elderly voters tend to be more supportive of school spending than middle-aged voters without children, a finding that is consistent with the hypothesis that the elderly are motivated by intergenerational altruism. While altruism could affect support for school spending at both the state and local level, we would argue that it is likely to have a much larger effect on support for local school spending. That would certainly be the case if middle-age and elderly voters without children had grandchildren who attended their community's local public schools or if they had friends with children in the local public schools. In any event, to the extent that older voters without children care more about the welfare of children in their own community than the welfare of children in other parts of the state, intergenerational altruism could explain why they have stronger preferences for local spending.

Is the apparent preference for local over statewide financing due to capitalization, or do local public schools inspire significant altruism among middle-age and elderly homeowners without children?

\footnotetext{
13 Poterba (1997, 1998) and Ladd and Murray (2001) discuss in detail other reasons why the elderly may continue to support public school spending. For example, Ladd and Murray (2001) note that if the elderly recognize the importance of having a well educated and highly paid work force, they may continue to support school spending in order to preserve the tax base necessary to finance programs that support the elderly in the future. However, it is unclear why this explanation would lead the elderly to prefer local over state spending on schools.
} 
The PPIC survey did not ask respondents why they intended to vote for or against an increase in state or local school spending and thus we can provide no direct evidence on whether capitalization or intergenerational altruism explains why older voters without children appear much more willing to support local spending than state spending on schools. Nevertheless, there may be an indirect way to distinguish between these two competing explanations.

As we noted above, even though older homeowners without children receive no direct benefit from an increase in local school spending, the capitalization of school spending into housing values may provide them with an indirect benefit. In contrast, older renters receive neither a direct nor an indirect benefit from an increase in local school spending: without school-age children they receive no direct benefit and without property they receive no indirect benefit. In fact, to the extent that increased school spending raises property values, they face the real possibility of paying higher rents if they support an increase in local school spending. As a result, if capitalization underlies the voting behavior we observe, older renters should be less willing to support an increase in local school spending than older homeowners. On the other hand, we have no reason to suspect that the degree of intergenerational altruism depends on homeownership. Thus, if intergenerational altruism underlies the voting behavior we observe, it seems likely that the voting behavior of older renters without children should be similar to the voting behavior of older homeowners without children.

To examine whether capitalization or intergenerational altruism better explains the voting pattern we observe, we estimated the same logit models as in Table 5, using a sample consisting exclusively of renters. Among the 591 renters without children or children in public school, one respondent did not answer the question about the presence of school-age children, two did not report their age, two did not report their educational attainment, one did not report the number of years they lived in their current residence, and one did not answer the question about future economic conditions, leaving a sample of 584 renters. Among these renters, 37 were college students. Because college students often attend schools located outside their local community or even their home state, they are likely to view increases in state or local spending differently than other renters. As a result, we eliminated college students from the sample leaving a final sample of 547 renters. 
Table 8

Binary Logit, Renters ( $\mathrm{N}=547)$

Standard Errors in Parenthesis

State Initiative

Local Initiative

\begin{tabular}{|c|c|c|c|c|}
\hline & \multicolumn{2}{|c|}{ State Initiative } & \multicolumn{2}{|c|}{ Local Initiative } \\
\hline Variable & Logit Coefficients & Marginal Effects & Logit Coefficients & Marginal Effects \\
\hline $\begin{array}{l}\text { Age Interacted with No } \\
\text { Children } \\
\quad \text { Age 35-44 }\end{array}$ & $\begin{array}{l}-1.76^{* *} \\
(0.38)\end{array}$ & $\begin{array}{l}-0.38^{* *} \\
(0.08)\end{array}$ & $\begin{array}{l}-1.19^{* *} \\
(0.38)\end{array}$ & $\begin{array}{l}-0.25^{* *} \\
(0.09)\end{array}$ \\
\hline Age 45-54 & $\begin{array}{l}-0.83^{* *} \\
(0.42)\end{array}$ & $\begin{array}{l}-0.15^{*} \\
(0.08)\end{array}$ & $\begin{array}{l}-0.75^{*} \\
(0.40)\end{array}$ & $\begin{array}{l}-0.142 * \\
(0.084)\end{array}$ \\
\hline Age 55-64 & $\begin{array}{l}-2.20^{* *} \\
(0.49)\end{array}$ & $\begin{array}{l}-0.48^{* *} \\
(0.10)\end{array}$ & $\begin{array}{l}-1.40^{* *} \\
(0.49)\end{array}$ & $\begin{array}{l}-0.30^{* *} \\
(0.12)\end{array}$ \\
\hline Age 65+ & $\begin{array}{l}-1.51^{* *} \\
(0.48)\end{array}$ & $\begin{array}{l}-0.32^{* *} \\
(0.11)\end{array}$ & $\begin{array}{c}0.26 \\
(0.67)\end{array}$ & $\begin{array}{l}0.037 \\
(0.09)\end{array}$ \\
\hline $\begin{array}{l}\text { Age Interacted with } \\
\text { Children in Public School } \\
\quad \text { Age 35-44 }\end{array}$ & $\begin{array}{l}-0.53 \\
(0.38)\end{array}$ & $\begin{array}{l}-0.09 \\
(0.07)\end{array}$ & $\begin{array}{l}-0.31 \\
(0.39)\end{array}$ & $\begin{array}{l}-0.05 \\
(0.07)\end{array}$ \\
\hline Age 45-54 & $\begin{array}{l}-0.81^{*} \\
(0.48)\end{array}$ & $\begin{array}{l}-0.15 \\
(0.10)\end{array}$ & $\begin{array}{l}-0.69 \\
(0.47)\end{array}$ & $\begin{array}{l}-0.13 \\
(0.10)\end{array}$ \\
\hline Age 55+ & $\begin{array}{l}-0.23 \\
(1.10)\end{array}$ & $\begin{array}{l}-0.04 \\
(0.18)\end{array}$ & $\begin{array}{l}-0.10 \\
(1.11)\end{array}$ & $\begin{array}{r}-0.016 \\
(0.18)\end{array}$ \\
\hline $\begin{array}{l}\text { Other Control Variables } \\
\text { Ideology }\end{array}$ & $\begin{array}{l}-0.47^{* *} \\
(0.12)\end{array}$ & $\begin{array}{l}-0.07^{* *} \\
(0.02)\end{array}$ & $\begin{array}{l}-0.29^{* *} \\
(0.11)\end{array}$ & $\begin{array}{l}-0.05^{* *} \\
(0.02)\end{array}$ \\
\hline White & $\begin{array}{l}-0.45^{*} \\
(0.26)\end{array}$ & $\begin{array}{l}-0.06^{*} \\
(0.03)\end{array}$ & $\begin{array}{l}-0.55^{* *} \\
(0.26)\end{array}$ & $\begin{array}{l}-0.07^{*} \\
(0.04)\end{array}$ \\
\hline Female & $\begin{array}{l}-0.06 \\
(0.25)\end{array}$ & $\begin{array}{l}-0.008 \\
(0.03)\end{array}$ & $\begin{array}{c}0.15 \\
(0.25)\end{array}$ & $\begin{array}{c}0.02 \\
(0.04)\end{array}$ \\
\hline Income & $\begin{array}{l}-0.22 * * \\
(0.10)\end{array}$ & $\begin{array}{l}-0.03^{*} \\
(0.016)\end{array}$ & $\begin{array}{l}-0.20^{* *} \\
(0.09)\end{array}$ & $\begin{array}{r}-0.03 * \\
(0.017)\end{array}$ \\
\hline College & $\begin{array}{r}0.58^{*} \\
(0.31)\end{array}$ & $\begin{array}{l}0.068^{*} \\
(0.038)\end{array}$ & $\begin{array}{r}0.60^{*} \\
(0.32)\end{array}$ & $\begin{array}{l}0.076^{*} \\
(0.04)\end{array}$ \\
\hline Outlook & $\begin{array}{l}0.68 * * \\
(0.27)\end{array}$ & $\begin{array}{l}0.08^{* *} \\
(0.03)\end{array}$ & $\begin{array}{l}0.81 * * \\
(0.28)\end{array}$ & $\begin{array}{l}0.10^{* *} \\
(0.04)\end{array}$ \\
\hline $\begin{array}{l}\text { Years in Current } \\
\text { Residence }\end{array}$ & $\begin{array}{c}0.12 \\
(0.14)\end{array}$ & $\begin{array}{c}0.02 \\
(0.02)\end{array}$ & $\begin{array}{c}0.06 \\
(0.15)\end{array}$ & $\begin{array}{c}0.01 \\
(0.02)\end{array}$ \\
\hline Constant & $\begin{array}{l}3.87 * * \\
(0.57)\end{array}$ & - & $\begin{array}{l}3.22 * * \\
(0.56)\end{array}$ & 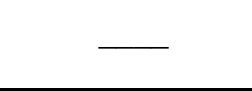 \\
\hline
\end{tabular}

*Significant at 10 percent level.

**Significant at 5 percent level. 
Results based on the sample of renters are reported in Table 8. In general the results do not strongly favor one explanation over the other. On the one hand, a comparison of the results reported in columns 4 and 5 of Tables 5 and 8 reveals that, relative to older homeowners without children, older renters without children appear less likely to support local spending. For example, with the exception of the coefficient on the age 65 or older dummy, all of the age coefficients for renters without children are negative and statistically significant at the ten-percent level or better. In contrast, only one of the age coefficients for homeowners without children is negative and statistically significant. Furthermore, a comparison of the marginal effects for the local regressions in Tables 5 and 8 reveals that, with the exception of the marginal effect for renters age 65 or older, the magnitude of the estimated marginal effects for the age dummies in the renter regression are all larger in magnitude than the corresponding marginal effects in the homeowner regression. ${ }^{14}$ For example, the results reported in Table 8 suggest that renters between the ages of 55 and 64 are 30 percentage points less likely to support the local initiative than younger renters. In contrast, the results reported in Table 5 suggest that homeowners between the ages of 55 and 64 are only 9 percentage points less likely to support the local initiative than younger homeowners. These findings are consistent with the hypothesis that capitalization leads older homeowners without children to prefer local over state spending on schools.

On the other hand, the results reported in Table 8 clearly show that, similar to older homeowners without children, older renters without children are much more likely to support local spending than state spending on schools. A comparison of the marginal effects reported in columns 3 and 5 of Table 8 reveals that age has a much larger effect on support for state spending than it does on support for local spending. For example, while renters age 65 or older are 32 percentage points less likely to vote yes on the statewide initiative than younger voters, they are no less likely to vote yes on the local initiative. That finding is consistent with the hypothesis that intergenerational altruism leads older voters without children to prefer local over state spending on schools.

Table A1 in the appendix reports coefficient estimates for the fixed-effects logit model using the sample of renters. The results reported in Table A1 once again do not strongly favor one explanation (capitalization or intergenerational altruism) over the other. With the exception of the coefficient on the age 65 or older dummy, all of the age coefficients for renters without children reported in column 3 of Table A1 are negative and statistically significant. In contrast, none of the age coefficients for homeowners without children reported in column 3 of Table 7 are statistically significant. That finding is consistent with the hypothesis that capitalization underlies the voting behavior of older voters without

${ }^{14}$ The marginal effects reported in Table 8 were evaluated at the same values of the independent variables used to calculate the marginal effects listed in Table 5, namely: under the age of 35, ideologically "middle of the road," white, female, income between $\$ 40,000$ and $\$ 59,999$, no college degree, a pessimistic view of future economic conditions, and 5 to 10 years in their current residence. 
children. However, the results reported in Table A1 also suggest that older renters are much more likely to support local spending than state spending on schools. That finding is consistent with the hypothesis that intergenerational altruism underlies the voting behavior of older voters without children.

One might argue the apparent preference among renters for local over state spending is simply due to renter allusion. It is well documented that renters tend to be much more willing to support increases in local expenditures than homeowners. Unlike homeowners, renters do not directly pay the property tax and therefore do not directly observe the tax-price associated with increases in local spending. As a result, they tend to be more willing than homeowners to support local spending increases. However, we question whether renter allusion can explain our results for two reasons. First, among renters 75 percent stated they would support the state initiative and 79 percent stated they would support the local initiative. Among homeowners 61 percent favored the state initiative and 69 favored the local initiative. Thus, while renters are 4 percentage points more likely to support local spending, homeowners are 8 percentage points more likely to support local spending. If renter allusion were driving our results we would expect renters to have much stronger preferences for local spending over state spending than homeowners. In fact, just the opposite is true. Second, if renters really believed they did not pay for local spending increases one would expect renters of all ages to equally favor local spending increases. The results reported in Table 8 and Table A1, however, indicate otherwise: older renters without children appear less supportive of local spending increases than younger voters.

\section{Conclusion}

In January of 2003, the Oregon state legislature asked voters to approve a statewide income tax measure that would restore funding for K-12 education and other government services that were scheduled to be cut due to budget shortfalls. Oregon voters rejected the measure. In May of 2003, voters in Beaverton Oregon were asked to approve a property tax increase to restore funding for their local public schools. Despite the fact that over 66 percent of households in Beaverton have no children in school, and a majority of voters in Beaverton opposed the statewide measure in January, in May nearly 60 percent of voters in Beaverton voted in favor of the local property tax increase. Evidently, voters in Beaverton were much more willing to support local spending on schools than state spending.

The recent election results in Oregon are consistent with the findings in this paper. Our results clearly show that older homeowners without children are more supportive of local spending on schools than state spending. It is less clear whether the higher support for local spending is motivated by capitalization or altruism. Our interpretation of the results reported in Table 8 is that both motives probably play important roles in maintaining support among older voters without children for local school spending. 
Our results also clearly show that both middle-age and elderly voters without children generally oppose state spending on schools. That finding may have important policy implications for the future of educational funding. Over the last three decades states across the country have transferred the authority for funding k-12 education from local communities to the state in response to court challenges over the constitutionality of their school finance systems. Our results suggest that the movement from local to state finance may have an adverse affect on support for school spending. If middle-age and elderly voters without children oppose state level spending on schools, support for K-12 education in states with state-financed systems will likely diminish.

Finally, concern over how an aging population will affect support for public school spending might be allayed by evidence that the elderly support spending to an unexpected degree, but only if this support is not unique to this generation of older voters. That is, will the baby boomers, a cohort that inevitably represents the largest-ever retiree proportion of the population, also support public school spending to the same degree as the current generation of retirees? Certainly evidence that school quality is capitalized into property values, and that voters are aware of this, suggests a permanent motivation for support of local school spending that is based on a broad conception of self-interest. But to the extent that support for school spending is driven by altruism, then continued support may depend on the source of that altruism. Our results indicate that baby-boom voters, ages 45 to 64 , may currently be slightly less supportive of state and local school spending than voters age 65 and over. If the generosity of the elderly is due to life-cycle effects, support for school spending, even state level spending, may increase among baby-boomers as they age. However, it may also be that current retirees are simply more altruistic than successive generations because of cohort or generational effects. If states and local school districts can not count on similar generosity from baby boomers in retirement, then the future adequacy of financing for public schools is a genuine concern. 


\section{References}

G. Auten, D. Joulfaian, Charitable Contributions and Intergenerational Transfers, Journal of Public Economics, 59 (1996) 55-68.

M. Baldassare, "PPIC Statewide Survey: Californians and their Government, October 2002," San Francisco, Cal.: Public Policy Institute of California, (2002).

T.C. Bergstrom, D.L. Rubinfeld and P. Shapiro, Micro-Based Estimates of Demand Functions for Local School Expenditures, Econometrica, 50 (1982) 1183-1206.

S.E. Black, Do Better Schools Matter? Parental Valuation of Elementary Education, Quarterly Journal of Economics, 114 (1999) 577-599.

W.T. Bogart and B.A. Cromwell, How Much More is a Good School District Worth?, National Tax Journal, 50 (1997) 215-232.

J.K. Brueckner and M. Joo, Voting with Capitalization, Regional Science and Urban Economics, 21 (1991) 453-467.

E. Brunner and J. Sonstelie, Homeowners, Property Values, and the Political Economy of the School Voucher, Journal of Urban Economics, forthcoming.

C.T. Clotfelter, The Economics of Giving, In: J.W. Barry and B.V. Manno (Ed.) Giving Better, Giving Smarter, Washington DC: National Commission of Philanthropy and Civic Renewal (1997).

C.T. Clotfelter, "Federal Tax Policy and Charitable Giving," Chicago: University of Chicago Press (1985).

W. A. Fischel, “The Homevoter Hypothesis,” Cambridge, Mass.: Harvard University Press (2001).

W. A. Fischel, Homevoters, Municipal Corporate Governance, and the Benefit View of the Property Tax, National Tax Journal, 54 (2001) 157-174.

A. R. Harris, W. N. Evans and R. M. Schwab, Education Spending in an Aging America, Journal of Public Economics, 81 (2001) 449-472.

D. Holtz-Eakin and H.S. Rosen, Municipal Construction Spending: An Empirical Examination. Economics and Politics, 5 (1993), 61-84.

R.P. Inman, Anatomy of a Fiscal Crisis, Philadelphia Federal Reserve Bank Business Review, Oct./Nov. (1983) 15-22.

H. F. Ladd and S. E. Murray, Intergenerational Conflict Reconsidered: County Demographic Structure and the Demand for Public Education, Economics of Education Review, 20 (2001) 343-357.

R.C. Mitchell and R.T. Carson, "Using Surveys to Value Public Goods: The Contingent Valuation Method," Washington, D.C.: Resources for the Future (1989). 
W.E. Oates, The Effects of Property Taxes and Local Public Spending on Property Values: An Empirical Study of Tax Capitalization and the Tiebout Hypothesis, Journal of Political Economy, 77 (1969) 957-971.

M. Ponza, G.J. Duncan, M. Corcoran and F. Groskind, The Guns of Autumn? Age Differences in Support for Income Transfers to the Young and Old, Public Opinion Quarterly, 52 (1988) 441-466.

J. M. Poterba, Demographic Structure and the Political Economy of Public Education, Journal of Policy Analysis and Management, 16 (1997) 48-66.

J. M. Poterba, Demographic Change, Intergenerational Linkages, and Public Education, American Economic Review, 88 (1998) 315-320.

R.D. Putnam, Tuning In, Tuning Out: The Strange Disappearance of Social Capital in America, P.S: Political Science and Politics, 28 (1995) 664-683.

W.C. Randolph, Dynamic Income, Progressive Taxes, and the Timing of Charitable Contributions, Journal of Political Economy, 103 (1995) 709-738.

D.L. Rubinfeld, Voting in a Local School Election: A Micro Analysis, Review of Economics and Statistics, 59 (1977) 30-42.

M. Vinovskis, An Historical Perspective on Support for Schooling by Different Age Cohorts, in: V.L. Bengtson and W.A. Achenbaum (Ed.), The Changing Contract Across Generations, New York, Aldine de Gruyter, 1993, pp. 45-65. 
Table A1

Fixed Effect Logit, Renters

Standard Errors in Parenthesis

\begin{tabular}{|c|c|c|}
\hline Variable & State Initiative & Local Initiative \\
\hline $\begin{array}{l}\text { Age Interacted with No Children } \\
\text { Age 35-44 }\end{array}$ & $\begin{array}{l}-1.58^{* *} \\
(0.39)\end{array}$ & $\begin{array}{l}-1.04^{* *} \\
(0.40)\end{array}$ \\
\hline Age $45-54$ & $\begin{array}{l}-0.62 \\
(0.45)\end{array}$ & $\begin{array}{l}-0.72 * \\
(0.42)\end{array}$ \\
\hline Age $55-64$ & $\begin{array}{l}-2.06^{* *} \\
(0.53)\end{array}$ & $\begin{array}{l}-1.16^{* *} \\
(0.55)\end{array}$ \\
\hline Age 65+ & $\begin{array}{l}-1.09 * * \\
(0.52)\end{array}$ & $\begin{array}{c}0.21 \\
(0.71)\end{array}$ \\
\hline $\begin{array}{l}\text { Age Interacted with Children in } \\
\text { Public School } \\
\quad \text { Age 35-44 }\end{array}$ & $\begin{array}{l}-0.14 \\
(0.41)\end{array}$ & $\begin{array}{l}-0.25 \\
(0.41)\end{array}$ \\
\hline Age $45-54$ & $\begin{array}{l}-0.78 \\
(0.50)\end{array}$ & $\begin{array}{l}-0.78 \\
(0.50)\end{array}$ \\
\hline Age 55+ & $\begin{array}{l}-0.28 \\
(1.14)\end{array}$ & $\begin{array}{l}-0.25 \\
(1.13)\end{array}$ \\
\hline $\begin{array}{l}\text { Other Control Variables } \\
\text { Ideology }\end{array}$ & $\begin{array}{l}-0.44^{* *} \\
(0.12)\end{array}$ & $\begin{array}{l}-0.28^{* *} \\
(0.12)\end{array}$ \\
\hline White & $\begin{array}{l}-0.68^{* *} \\
(0.29)\end{array}$ & $\begin{array}{l}-0.46^{*} \\
(0.29)\end{array}$ \\
\hline Female & $\begin{array}{l}-0.03 \\
(0.26)\end{array}$ & $\begin{array}{c}0.16 \\
(0.27)\end{array}$ \\
\hline Income & $\begin{array}{l}-0.16^{*} \\
(0.10)\end{array}$ & $\begin{array}{l}-0.18^{*} \\
(0.10)\end{array}$ \\
\hline College & $\begin{array}{l}0.67^{* *} \\
(0.33)\end{array}$ & $\begin{array}{c}0.66^{*} \\
(0.34)\end{array}$ \\
\hline Outlook & $\begin{array}{l}0.75^{* *} \\
(0.28)\end{array}$ & $\begin{array}{l}0.74 * * \\
(0.29)\end{array}$ \\
\hline $\begin{array}{l}\text { Years in Current } \\
\text { Residence }\end{array}$ & $\begin{array}{c}0.07 \\
(0.15) \\
\end{array}$ & $\begin{array}{l}-0.02 \\
(0.16)\end{array}$ \\
\hline Observations & 492 & 484 \\
\hline
\end{tabular}

*Significant at 10 percent level.

**Significant at 5 percent level. 